\title{
Response of Ground Beetle (Coleoptera: Carabidae) Communities to Effect of Urbanization in Southern Osaka: An Analytical Approach Using GIS
}

\author{
Jin-Wook Park ${ }^{1}$ and Cheol Min Lee ${ }^{2, *}$ \\ 1 Department of Landscape Architecture, Daegu Catholic University, 13-13 Hayang-ro, Hayang-eup, \\ Gyeongsan-si, Daegu 38430, Korea; parkjw@cu.ac.kr \\ 2 California Department of Food and Agriculture, 2710 Gateway Oaks Drive, Sacramento, CA 95833, USA \\ * Correspondence: Cheolmin.Lee@cdfa.ca.gov; Tel.: +1-714-580-2234
}

check for updates

Citation: Park, J.-W.; Lee, C.M. Response of Ground Beetle (Coleoptera: Carabidae) Communities to Effect of Urbanization in Southern Osaka: An Analytical Approach Using GIS. Sustainability 2021, 13 , 7134. https://doi.org/10.3390/ su13137134

Academic Editors: Volker Mauerhofer and Ranjay K. Singh

Received: 2 May 2021

Accepted: 22 June 2021

Published: 25 June 2021

Publisher's Note: MDPI stays neutral with regard to jurisdictional claims in published maps and institutional affiliations.

Copyright: (C) 2021 by the authors. Licensee MDPI, Basel, Switzerland. This article is an open access article distributed under the terms and conditions of the Creative Commons Attribution (CC BY) license (https:// creativecommons.org/licenses/by/ $4.0 /)$.

\begin{abstract}
Urbanization involves the profound alteration of original habitats and causes habitat loss and biodiversity decline. This study aims to clarify the response of ground beetle communities to the effect of urbanization in southern Osaka, Japan. In total, 2950 individuals from 53 species of ground beetle were collected in nine urban green areas. The categories of land use regarding the study sites were determined based on GIS data. The community index was not significantly different between areas. Urban areas and roads in land use mainly have a negative influence on ground beetles. Paddies, fields, parks and green spaces, and open space were positively correlated with species richness of forest species and large-sized species, and open space was positively correlated with species richness and the density of open land species. However, ground beetle communities in different areas of varying sizes did not group separately. These results suggest that changes in paddies, fields, parks and green spaces, forests, and open space associated with the expanding urban area and road greatly influenced species composition, and the community structure remained similar.
\end{abstract}

Keywords: ground beetle; urbanization; land use; urban green area; GIS

\section{Introduction}

Urbanization drives global environmental changes and is one of the major anthropogenic activities that impacts biodiversity and ecosystem processes [1-3]. Currently, 55\% of the global human population lives in urban areas, and this trend is expected to continue in the coming decades [4]. Urbanization has a significant impact on abiotic and biotic factors in nature and leads to substantial changes in natural habitats with profound effects on wildlife and their activity pattern, spatial distribution, phenology, productivity, and biotic interactions [5-7]. The diversity and community structure of wildlife will change significantly in urban habitats compared with rural ones [3,8-10].

Ground beetles are useful bio-indicators because they are sufficiently varied both taxonomically and ecologically, abundant, and sensitive to the anthropogenic effect [11,12]. Urbanization has a huge effect at various levels of the biological organization on ground beetles in urban habitats [13]. Ground beetles with large body sizes, predatory feeding habits, strict forest habitat requirements, and poor dispersal ability were most sensitive to urbanization [6]. Many studies have been conducted to clarify the relationships between ground beetle diversity and the effect of urbanization according to the urban-rural gradient $[8,14,15]$.

There is a need for studies on the responses of ground beetle communities according to different areas and land use. To our knowledge, this is the first study to clarify the response of ground beetles to the effect of urbanization using the GIS method. This study was carried out in nine urban green areas in southern Osaka. We tested the following questions: (1) How does the ground beetle community respond according to the area and 
land use? (2) Which species are more vulnerable to the effect of urbanization? (3) Which environmental factors influence positively, or negatively, the ground beetle community? Finally, we propose an alternative to improve ground beetle diversity in urban areas.

\section{Materials and Methods}

\subsection{Study Sites}

Osaka Prefecture is the second largest metropolitan area in Japan, and its area is about $1905 \mathrm{~km}^{2}$ and the population is about 8.8 million as of April 2021. Osaka Prefecture is surrounded by Mt. Izumikatsuragi, Mt. Iwawaki, Mt. Kongo, Mt. Iwahashiyama, and Mt. Ikoma. Yodo River and Yamato River flow through Osaka. Many areas in Osaka are comprised of houses, apartments, and other buildings (Figure 1). However, Osaka Prefecture has remnant forests between mountain areas and flatland areas, and paddy fields in suburban areas. There are also large urban green areas, such as urban parks, urban forests, temples, shrines, university campuses, etc. Urban green areas have been fragmented by urban areas and separated from other surrounding natural areas. However, urban green areas play an important role in maintaining water and air quality, providing wildlife habitat, and supporting meta-populations of regional flora and fauna, as well as recreational areas for human wellbeing $[2,16,17]$. The urban green areas should be properly evaluated to maintain their ecological value in the urban ecosystem.

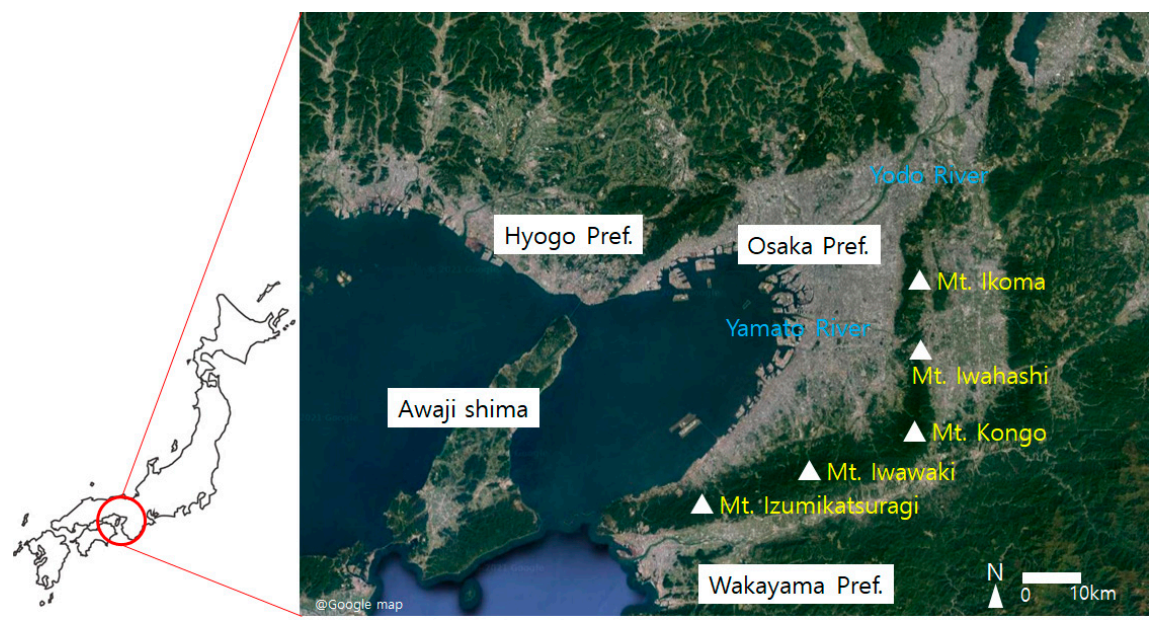

Figure 1. Map of study area.

We chose nine urban green areas in southern Osaka (Figure 2). Suzunomiya park (SU), Chayama park $(\mathrm{CH})$, Niwasiro park (NI), and Kouzen park $(\mathrm{KO})$ are surrounded by residential areas, apartment complexes, and roads. Izumigaokaryokuchi (IZ), Kurotoriyama park (KU), and Koumyouike park (KM) are partially connected to natural habitats. Takasago park (TA) and Umitonohureaihiroba (UM) are located in landfill areas. The detailed information of each site is included in Table 1. The nine urban green areas were classified into three groups based on size: small area $(<5 \mathrm{ha})$, medium area ( $>5$ ha and $<15 \mathrm{ha})$, and large area ( $>15 \mathrm{ha})$. 


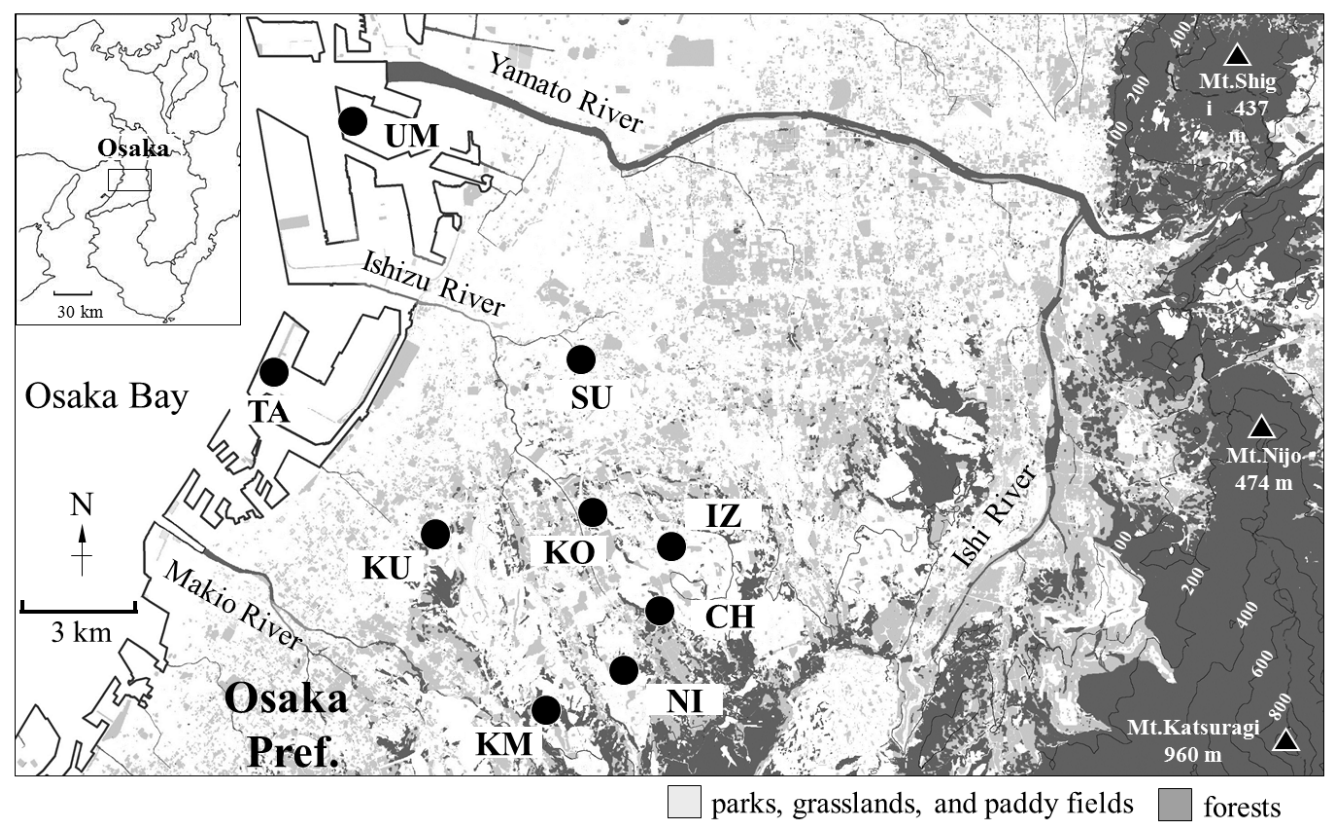

Figure 2. Map of the study sites. SU: Suzunomiya park, CH: Chayama park, TA: Takasago park, IZ: Izumigaokaryokuchi, NI: Niwasiro park, KU: Kurotoriyama park, UM: Umitonohureaihiroba, KO: Kouzen park, KM: Koumyouike park.

\subsection{Survey and Ground Beetle Identification}

The survey was carried out 18 times from April to December 2007 using pitfall traps in nine urban green areas in southern Osaka. A plastic cup (diameter $7 \mathrm{~cm}$, depth $10 \mathrm{~cm}$ ) was used to make a trap without using any bait, and five holes were made to avoid rainwater. Ten traps were set $5 \mathrm{~m}$ apart in a straight line in the grassland area and another 10 traps in the forest area for 7 days at each site. As some traps were lost during the survey period, 346, $321,357,333,297,342,345,307$, and 297 traps were collected from SU to KM, respectively. The ground beetle specimens were identified using taxonomic keys [18] to the level of species under a stereoscopic microscope.

\subsection{Body Size and Habitat Type}

The body size of ground beetles was grouped into three size classes: small $(<10.0 \mathrm{~mm})$, medium $(11.0-20.0 \mathrm{~mm})$, and large $(>21.0 \mathrm{~mm})$ based on Ueno et al. [18]. In terms of habitat type, the ground beetles were classified into two groups based on their location when collected. Forest species were mainly recorded in forests such as broadleaf forests, pine forests, urban forests, and secondary forests, whereas open land species were mainly recorded on riverbanks, paddy fields, urban green areas, and urban parks. If a species was recorded in more than one habitat, the habitat where the species was more frequent was used. Habitat type was determined based on Ueno et al. [18], Lee [19], and Lake Biwa Museum [20].

\subsection{Land Use Analysis}

The land use data were collected from a 1:5000 scale map published in 2001 by the Geospatial Information Authority of Japan. The patterns of the surrounding environment of survey routes in nine urban green areas were analyzed using GIS. There is no standard method or previous study that suggested an appropriate radius for considering the influence of urbanization on ground beetle communities. A $1 \mathrm{~km}$ radius in the urban green areas in southern Osaka included some natural habitats. A previous study suggested that a circle of $500 \mathrm{~m}$ radius was appropriate for considering the impact of urbanization on ground arthropods [21]. The land use was classified into ten categories: paddy, field, park and green space, forest, urban area, road, open space, river and pond, sea, and others. 
Table 1. Summary of study sites.

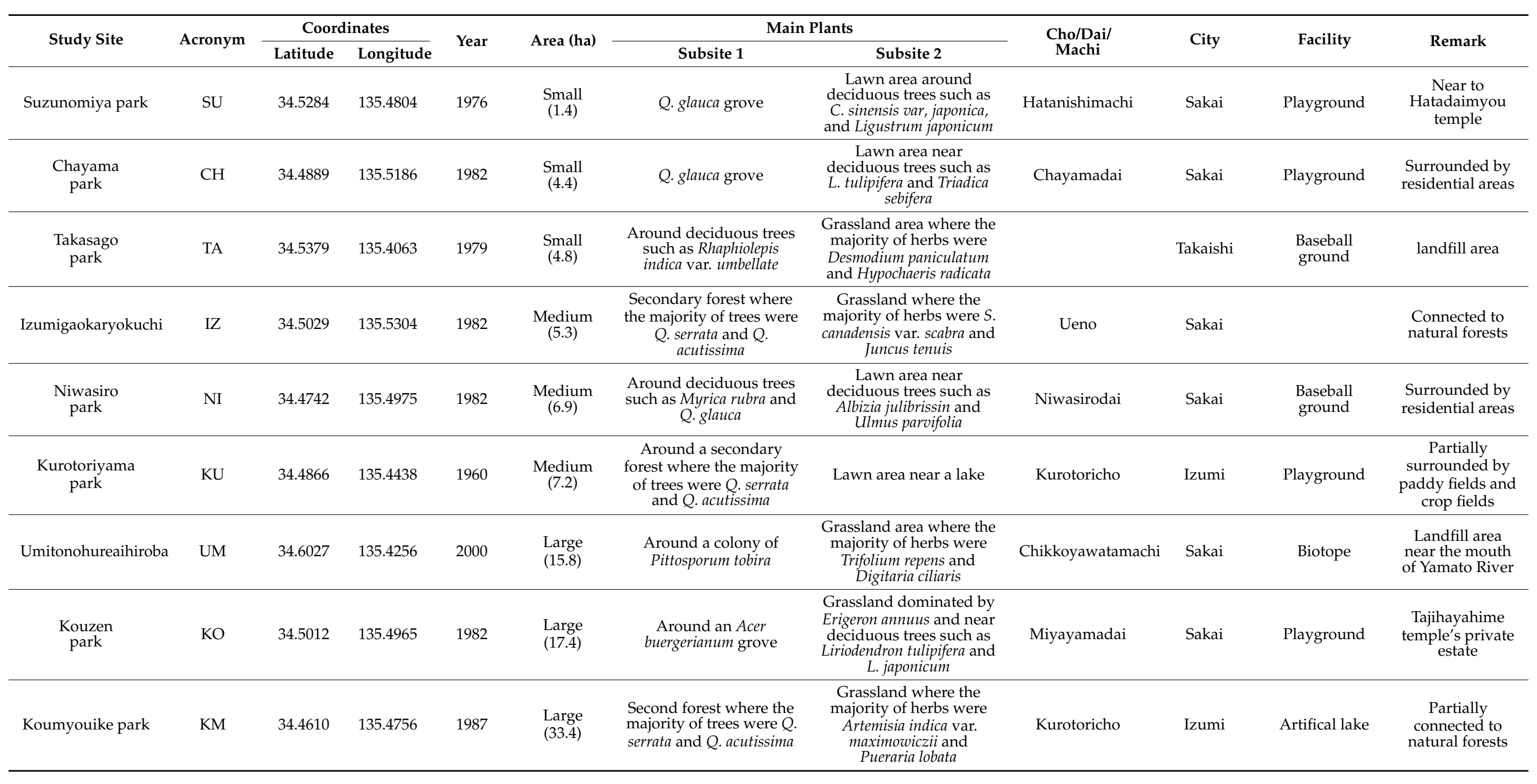




\subsection{Data Analysis}

A one-way ANOVA was used to verify the differences in species richness and density of body size and habitat type, species diversity $\left(H^{\prime}\right)$, and species evenness $\left(J^{\prime}\right)$ between different areas. The relationships between eight categories of land use and the ground beetles index were examined using Pearson's correlation analysis. Ground beetle communities were ordinated using non-metric multidimensional scaling (NMDS). Singleton species occurring on one site were excluded from NMDS ordination. NMDS ordination, species diversity, and species evenness were calculated using Vegan R package (ver. 2.5-6). All statistical analyses were performed using R 4.0.3 [22].

\section{Results}

A total of 2950 ground beetles representing 53 species were collected (Table 2). Species richness was the highest at UM (30 species) near the mouth of Yamato River and the lowest at TA (4 species) in the landfill area in Takaishi city. Density was the highest at IZ (59.76) and the lowest at TA (1.24). Species diversity and evenness broadly ranged from 1.12 to 2.80 and from 0.42 to 0.89 , respectively. Synuchus nitidus was the most abundant species, with 951 individuals (32.2\% of all individuals). S. dulcigradus (20.9\%) and Dolichus halensis $(10.1 \%)$ were also abundant. Three dominant species accounted for $63.3 \%$ of all individuals. When body size was considered, 30 medium-sized species, 16 small-sized species, and 7 large-sized species were found (Table 2). Species richness of small-sized species and medium-sized species was the highest at NI (8) and UM (19), respectively, but the lowest at TA (1 and 3, Figure 3). Species richness of large-sized species was the highest at KM (5). However, large-sized species were not found in SU, CH, TA, or NI. The density of small-sized species and medium-sized species was the highest at IZ (26.07 and 33.15) and the lowest at TA ( 0.28 and 0.56$)$. The density of large-sized species was the highest at KU (2.22). In terms of habitat type, 13 forest species and 40 open land species were found. Species richness of forest species were the highest at IZ and KM (10) and the lowest at TA (1). Species richness and density of open land species were the highest at UM (28 and 25.80) and the lowest at TA ( 3 and 0.78 ).
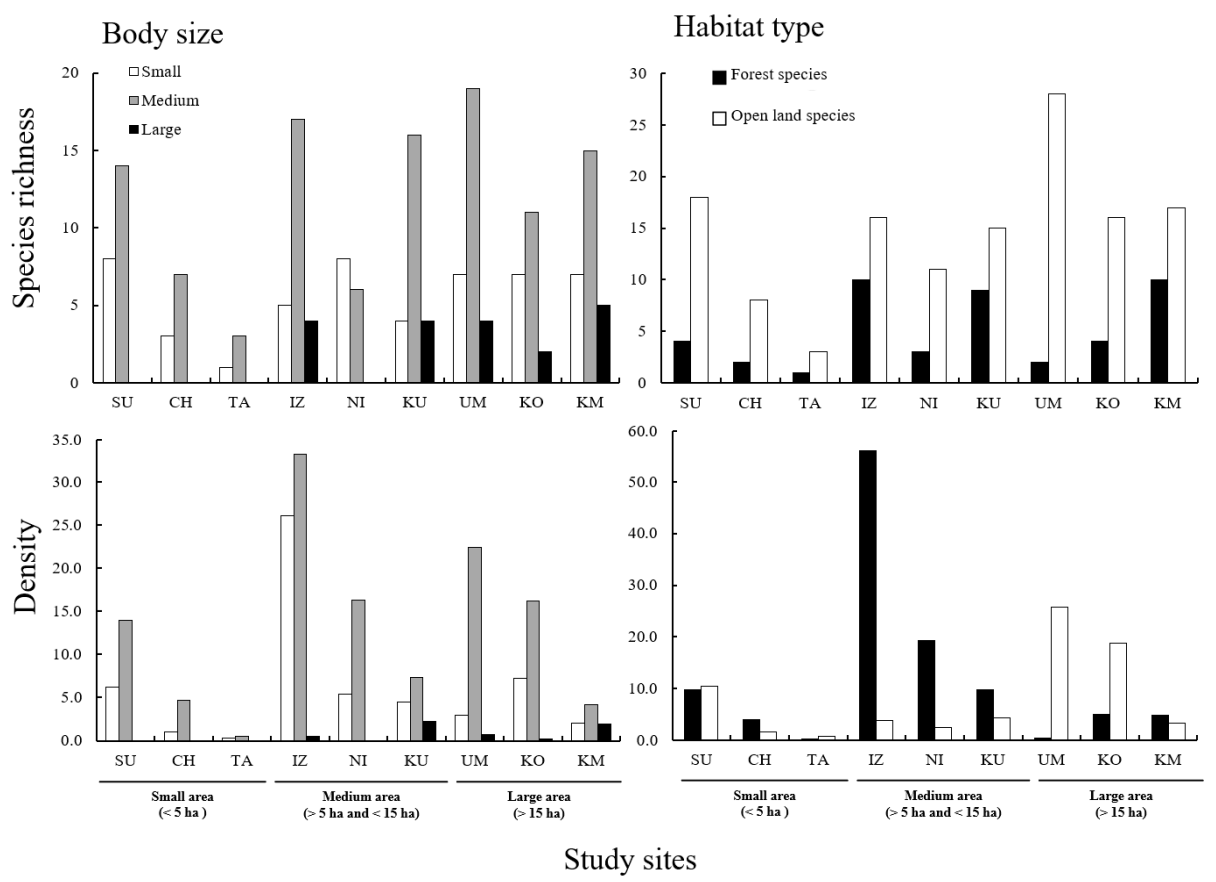

Figure 3. Species richness and density (abundance per 20 traps) according to body size and habitat type of ground beetles in nine urban green areas. SU: Suzunomiya park, CH: Chayama park, TA: Takasago park, IZ: Izumigaokaryokuchi, NI: Niwasiro park, KU: Kurotoriyama park, UM: Umitonohureaihiroba, KO: Kouzen park, KM: Koumyouike park. 
Table 2. Ground beetles collected using pitfall traps in nine urban green areas in southern Osaka.

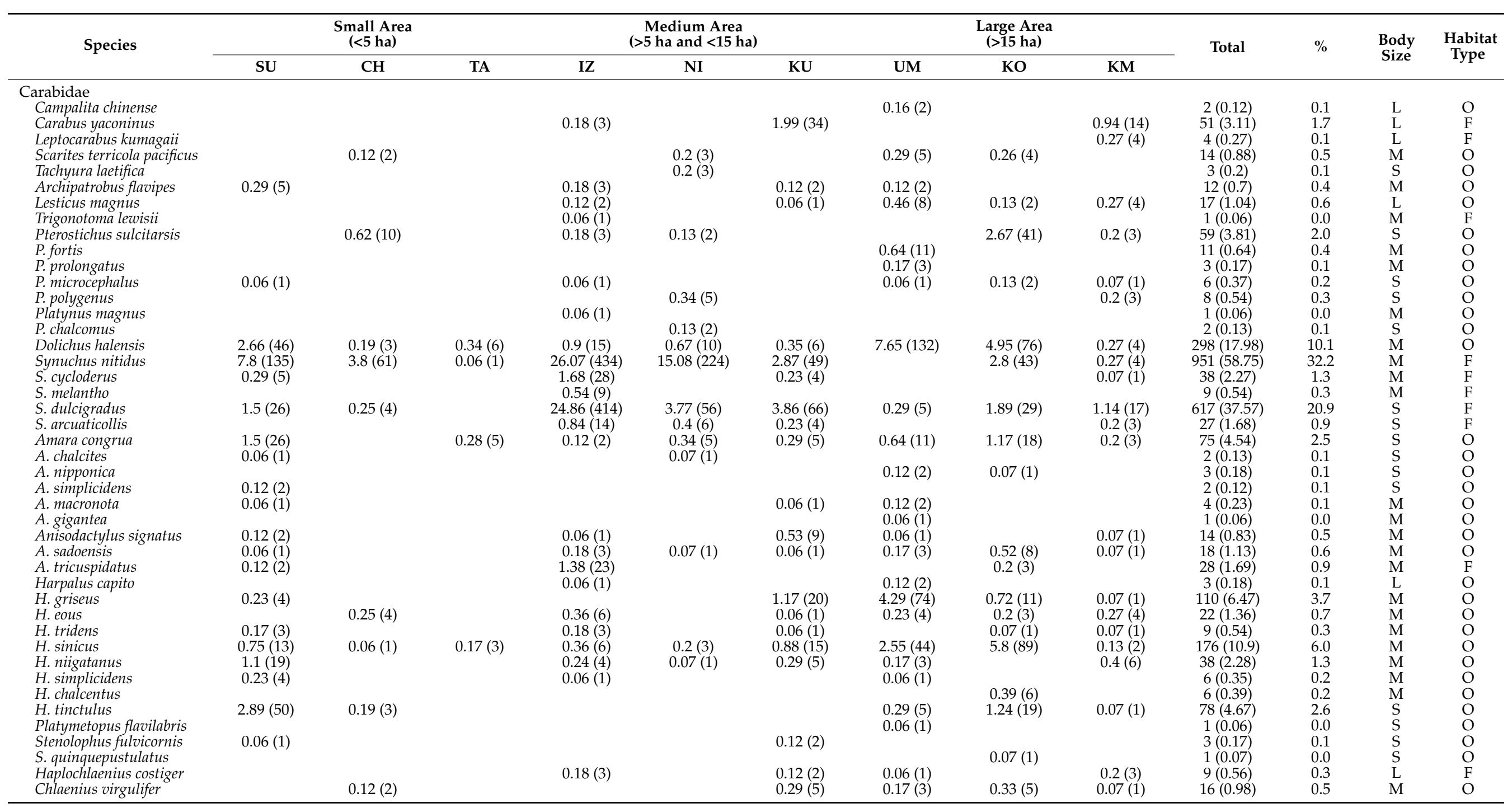


Table 2. Cont.

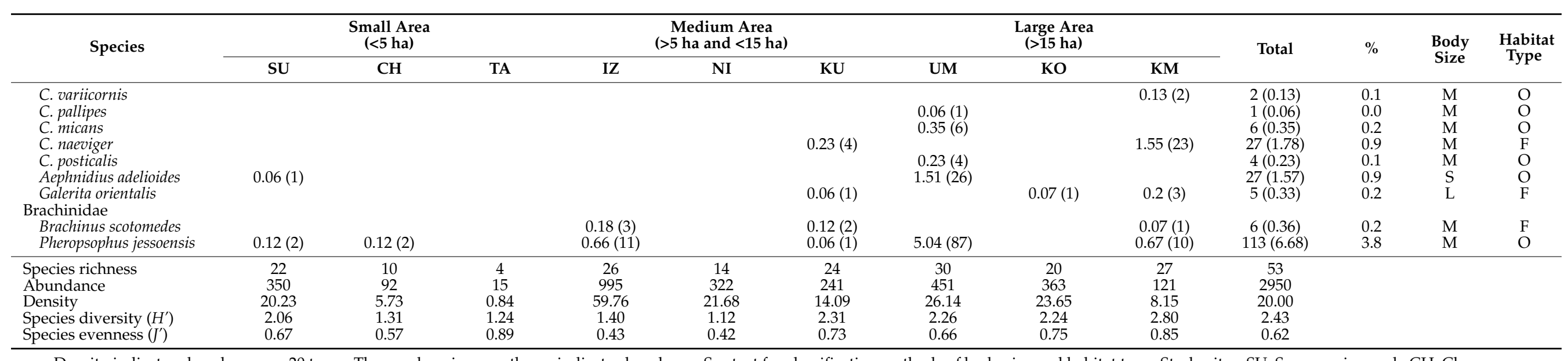

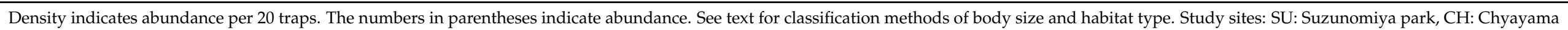

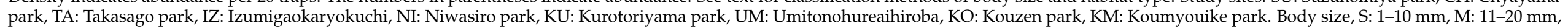
L: 21-50 mm. Habitat type, F: forest species, O: open land species. 
Species richness, density, species diversity, and species evenness were not significantly different between different areas (Table 3). The percentage of urban area in the nine urban green areas was over $50 \%$ except for $\mathrm{KO}, \mathrm{KU}$, and $\mathrm{UM}$, whereas that of forest was below $19 \%$ (Table 4 ). The percentage of road was over $11 \%$ except for KM, TA, KU, and UM. The community index showed various responses according to different land use categories (Table 5). Ground beetle species richness, species richness of small, medium, and large size, and open land species were negatively correlated with urban area and road, whereas they were positively correlated with open space. The density of large-sized species was positively correlated with area, paddy, field, and forest, whereas it was negatively correlated with urban area and road. Species richness of small-sized species was positively correlated with year and open space, whereas it was negatively correlated with park and green space, forest, urban area, and road. Similarity relationships among ground beetle communities were visualized using two-dimensional NMDS ordination (Figure 4). Ground beetle communities in different areas of varying sizes did not group separately $(\mathrm{F}=1.43$, $\mathrm{df}=2, \mathrm{r}^{2}=0.32, p=0.076$ ).

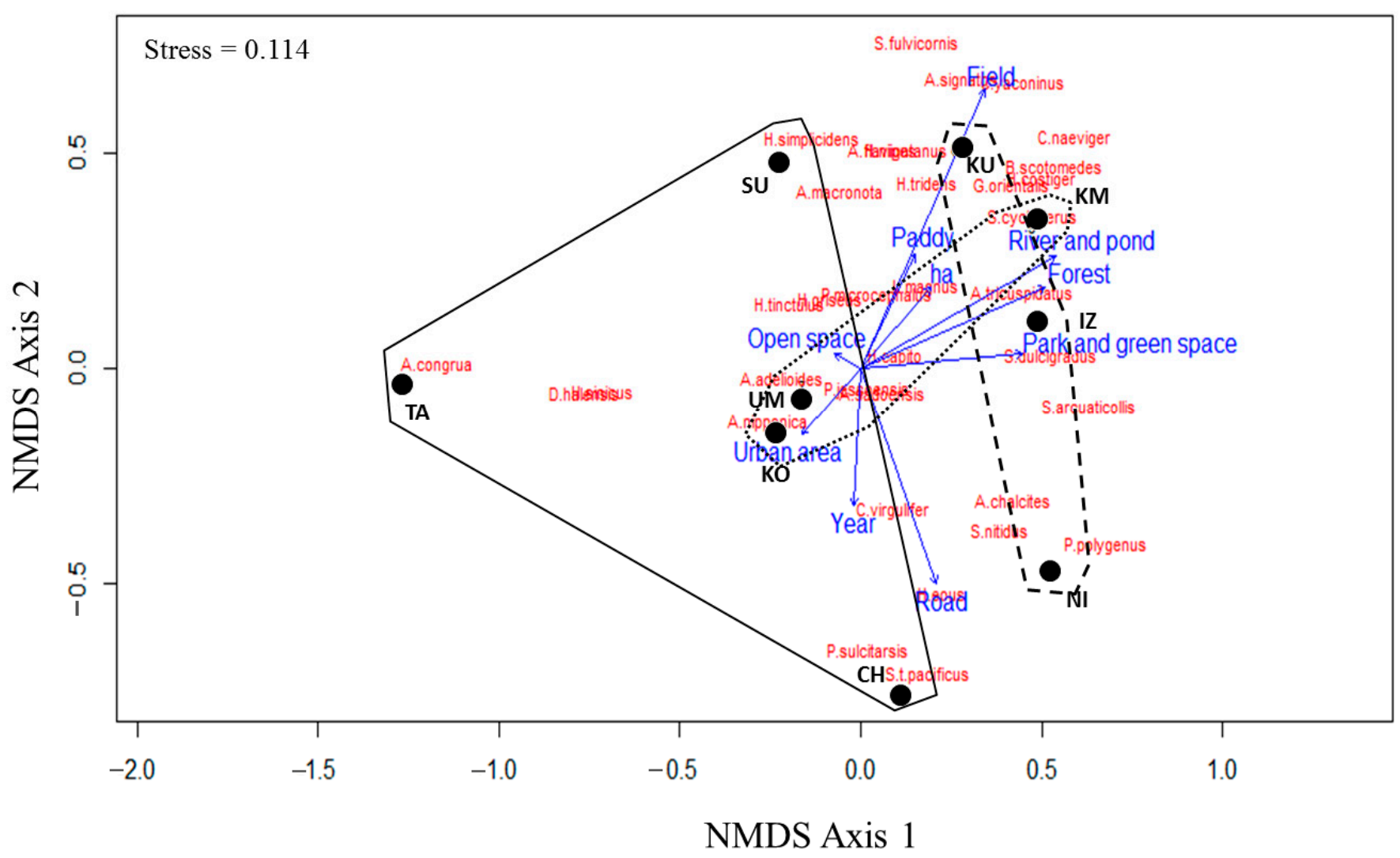

Figure 4. Non-metric multidimensional scaling (NMDS) ordination of ground beetle communities in nine urban green areas. Singleton species occurring at one site were excluded from the NMDS ordination. Solid line indicates communities in small area, dashed line indicates communities in medium area, and dotted line indicates communities in large area. SU: Suzunomiya park, CH: Chayama park, TA: Takasago park, IZ: Izumigaokaryokuchi, NI: Niwasiro park, KU: Kurotoriyama park, UM: Umitonohureaihiroba, KO: Kouzen park, KM: Koumyouike park. 
Table 3. Species richness, density, body size, and habitat type of species richness and density, species diversity, and species evenness according to urban green area.

\begin{tabular}{|c|c|c|c|c|c|}
\hline \multirow{2}{*}{ Community Index } & \multicolumn{3}{|c|}{ Area } & \multicolumn{2}{|c|}{$\begin{array}{l}\text { One-Way } \\
\text { ANOVA }\end{array}$} \\
\hline & $\begin{array}{l}\text { Small Area } \\
\qquad(<5 \text { ha })\end{array}$ & $\begin{array}{c}\text { Medium Area } \\
(>5 \text { ha and }<15 \text { ha })\end{array}$ & $\begin{array}{c}\text { Large Area } \\
\text { (>15 ha) }\end{array}$ & $F_{2,6}$ & $p$ \\
\hline \multicolumn{6}{|l|}{ Species richness } \\
\hline All species & $12.0 \pm 5.29$ & $21.3 \pm 3.71$ & $25.7 \pm 2.96$ & 2.90 & 0.132 \\
\hline \multicolumn{6}{|l|}{ Body size } \\
\hline Small & $4 \pm 2.08$ & $5.7 \pm 1.20$ & $7.0 \pm 0.00$ & 1.17 & 0.372 \\
\hline Medium & $8.0 \pm 3.21$ & $13.0 \pm 3.51$ & $15.0 \pm 2.31$ & 1.39 & 0.319 \\
\hline Large & 0.0 & $2.7 \pm 1.33$ & $3.7 \pm 0.88$ & 4.22 & 0.072 \\
\hline \multicolumn{6}{|l|}{ Habitat type } \\
\hline Forest species & $2.3 \pm 0.88$ & $7.3 \pm 2.19$ & $5.3 \pm 2.40$ & 1.68 & 0.264 \\
\hline Open land species & $9.7 \pm 4.41$ & $14.0 \pm 1.53$ & $20.3 \pm 3.84$ & 2.36 & 0.175 \\
\hline \multicolumn{6}{|l|}{ Density } \\
\hline All species & $8.93 \pm 5.82$ & $31.85 \pm 14.13$ & $19.31 \pm 5.63$ & 1.49 & 0.299 \\
\hline \multicolumn{6}{|l|}{ Body size } \\
\hline Small & $2.53 \pm 1.87$ & $11.99 \pm 7.04$ & $4.09 \pm 1.59$ & 1.39 & 0.320 \\
\hline Medium & $6.41 \pm 3.97$ & $18.94 \pm 7.56$ & $14.28 \pm 5.36$ & 1.19 & 0.368 \\
\hline Large & 0.00 & $0.92 \pm 0.67$ & $0.94 \pm 0.50$ & 1.26 & 0.350 \\
\hline \multicolumn{6}{|l|}{ Habitat type } \\
\hline Forest species & $4.61 \pm 2.80$ & $28.31 \pm 14.10$ & $3.40 \pm 1.53$ & 2.83 & 0.136 \\
\hline Open land species & $4.33 \pm 3.11$ & $3.53 \pm 0.58$ & $15.91 \pm 6.66$ & 2.65 & 0.150 \\
\hline Species diversity $\left(H^{\prime}\right)$ & $1.54 \pm 0.26$ & $1.61 \pm 0.36$ & $2.43 \pm 0.18$ & 3.21 & 0.113 \\
\hline Species evenness $\left(J^{\prime}\right)$ & $0.71 \pm 0.09$ & $0.53 \pm 0.10$ & $0.75 \pm 0.05$ & 1.95 & 0.223 \\
\hline
\end{tabular}

Table 4. Area (ha) and percentage of land use categories within the range of $500 \mathrm{~m}$ from the edge of nine urban green areas.

\begin{tabular}{|c|c|c|c|c|c|c|c|c|c|c|c|c|c|}
\hline \multicolumn{3}{|c|}{ Land Use Category } & \multirow{2}{*}{$\begin{array}{c}\text { Paddy } \\
3.9\end{array}$} & \multirow{2}{*}{$\begin{array}{c}\text { Field } \\
5.9\end{array}$} & \multirow{2}{*}{$\begin{array}{c}\text { Park and } \\
\text { Green } \\
\text { Space }\end{array}$} & \multirow{2}{*}{$\begin{array}{c}\text { Forest } \\
2.0\end{array}$} & \multirow{2}{*}{$\begin{array}{c}\begin{array}{c}\text { Urban } \\
\text { Area }\end{array} \\
81.9\end{array}$} & \multirow{2}{*}{$\begin{array}{c}\text { Road } \\
13.0\end{array}$} & \multirow{2}{*}{$\begin{array}{c}\begin{array}{c}\text { Open } \\
\text { Space }\end{array} \\
6.4\end{array}$} & \multirow{2}{*}{$\begin{array}{c}\begin{array}{c}\text { River } \\
\text { and } \\
\text { Pond }\end{array} \\
0.2\end{array}$} & \multirow{2}{*}{$\begin{array}{c}\text { Sea } \\
0.0\end{array}$} & \multirow{2}{*}{$\begin{array}{c}\text { Others } \\
0.0\end{array}$} & \multirow{2}{*}{$\begin{array}{l}\text { Total } \\
116.4\end{array}$} \\
\hline \multirow{6}{*}{$\begin{array}{l}\text { Small area } \\
\quad(<5 \mathrm{ha})\end{array}$} & \multirow{2}{*}{ SU } & ha & & & & & & & & & & & \\
\hline & & $\%$ & 3.4 & 5.1 & 2.6 & 1.8 & 70.4 & 11.2 & 5.5 & 0.2 & 0.0 & 0.0 & 100.0 \\
\hline & \multirow{2}{*}{$\mathrm{CH}$} & ha & 0.0 & 0.4 & 9.0 & 13.4 & 73.1 & 22.2 & 4.2 & 0.7 & 0.0 & 0.0 & 123.0 \\
\hline & & $\%$ & 0.0 & 0.4 & 7.3 & 10.9 & 59.4 & 18.0 & 3.4 & 0.6 & 0.0 & 0.0 & 100.0 \\
\hline & \multirow{2}{*}{$\mathrm{TA}$} & ha & 0.0 & 0.0 & 2.5 & 0.0 & 89.3 & 7.9 & 4.3 & 0.0 & 19.7 & 0.0 & 123.6 \\
\hline & & $\%$ & 0.0 & 0.0 & 2.0 & 0.0 & 72.3 & 6.4 & 3.5 & 0.0 & 15.9 & 0.0 & 100.0 \\
\hline \multirow{6}{*}{$\begin{array}{c}\text { Medium area } \\
(>5 \text { ha and }<15 \text { ha })\end{array}$} & \multirow{2}{*}{ IZ } & ha & 5.5 & 11.9 & 6.2 & 11.8 & 68.7 & 20.1 & 2.9 & 11.5 & 0.0 & 0.0 & 138.5 \\
\hline & & $\%$ & 4.0 & 8.6 & 4.5 & 8.5 & 49.6 & 14.5 & 2.1 & 8.3 & 0.0 & 0.0 & 100.0 \\
\hline & \multirow{2}{*}{$\mathrm{NI}$} & ha & 6.2 & 2.5 & 4.5 & 8.9 & 93.6 & 21.4 & 6.1 & 5.6 & 0.0 & 0.0 & 148.7 \\
\hline & & $\%$ & 4.2 & 1.7 & 3.0 & 6.0 & 62.9 & 14.4 & 4.1 & 3.7 & 0.0 & 0.0 & 100.0 \\
\hline & \multirow{2}{*}{ KU } & ha & 15.5 & 16.1 & 10.6 & 28.4 & 49.2 & 4.7 & 7.3 & 7.6 & 0.0 & 11.8 & 151.2 \\
\hline & & $\%$ & 10.3 & 10.6 & 7.0 & 18.8 & 32.5 & 3.1 & 4.8 & 5.0 & 0.0 & 7.8 & 100.0 \\
\hline \multirow{6}{*}{$\begin{array}{l}\text { Large area } \\
(>15 \mathrm{ha})\end{array}$} & \multirow{2}{*}{$\mathrm{UM}$} & ha & 0.0 & 0.0 & 0.0 & 0.0 & 2.6 & 0.0 & 61.6 & 0.0 & 115.2 & 0.0 & 179.3 \\
\hline & & $\%$ & 0.0 & 0.0 & 0.0 & 0.0 & 1.4 & 0.0 & 34.3 & 0.0 & 64.2 & 0.0 & 100.0 \\
\hline & \multirow{2}{*}{$\mathrm{KO}$} & ha & 25.5 & 7.6 & 4.0 & 14.9 & 82.4 & 22.7 & 7.6 & 6.0 & 0.0 & 0.0 & 170.7 \\
\hline & & $\%$ & 15.0 & 4.4 & 2.4 & 8.7 & 48.3 & 13.3 & 4.4 & 3.5 & 0.0 & 0.0 & 100.0 \\
\hline & \multirow{2}{*}{$\mathrm{KM}$} & ha & 16.5 & 19.6 & 22.3 & 43.8 & 167.4 & 29.2 & 23.4 & 12.9 & 0.0 & 0.0 & 335.0 \\
\hline & & $\%$ & 4.9 & 5.8 & 6.7 & 13.1 & 50.0 & 8.7 & 7.0 & 3.9 & 0.0 & 0.0 & 100.0 \\
\hline
\end{tabular}

Study sites; SU: Suzunomiya park, CH: Chayama park, TA: Takasago park, IZ: Izumigaokaryokuchi, NI: Niwasiro park, KU: Kurotoriyama park, UM: Umitonohureaihiroba, KO: Kouzen park, KM: Koumyouike park. 
Table 5. Pearson's correlation coefficient between ground beetles index and land use category of nine urban green areas.

\begin{tabular}{|c|c|c|c|c|c|c|c|c|c|c|}
\hline Community Index & Year & Area (ha) & Paddy & Field & $\begin{array}{l}\text { Park and Green } \\
\text { Space }\end{array}$ & Forest & Urban Area & Road & Open Space & River and Pond \\
\hline $\begin{array}{l}\text { Species richness } \\
\text { All species } \\
\text { Bodv size }\end{array}$ & 0.333 & $0.591 * *$ & 0.234 & 0.305 & -0.288 & 0.022 & $-0.900 * * *$ & $-0.806^{* * *}$ & $0.702 * * *$ & 0.081 \\
\hline $\begin{array}{l}\text { Small } \\
\text { Medium } \\
\text { Large }\end{array}$ & $\begin{array}{c}0.639 * * * \\
0.287 \\
0.061\end{array}$ & $\begin{array}{c}0.379 \\
0.527^{* *} \\
0.692 * * *\end{array}$ & $\begin{array}{l}0.017 \\
0.215 \\
0.369\end{array}$ & $\begin{array}{c}-0.235 \\
0.349 \\
0.515 *\end{array}$ & $\begin{array}{c}-0.700^{* * *} \\
-0.254 \\
0.085\end{array}$ & $\begin{array}{l}-0.490 * \\
0.047 \\
0.374\end{array}$ & $\begin{array}{l}-0.612^{* *} \\
-0.891^{* * *} \\
-0.791^{* * *}\end{array}$ & $\begin{array}{l}-0.476^{*} \\
-0.796^{* * *} \\
-0.774^{* * *}\end{array}$ & $\begin{array}{c}0.707^{* * *} \\
0.675^{* * *} \\
0.479^{*}\end{array}$ & $\begin{array}{l}-0.321 \\
0.125 \\
0.265\end{array}$ \\
\hline $\begin{array}{l}\text { Habitat type } \\
\text { Forest species } \\
\text { Open land species }\end{array}$ & $\begin{array}{c}-0.654^{* * * *} \\
0.644^{* * *}\end{array}$ & $\begin{array}{l}0.172 \\
0.562^{* *}\end{array}$ & $\begin{array}{c}0.641^{* * *} \\
-0.026\end{array}$ & $\begin{array}{c}0.960 * * * \\
-0.089\end{array}$ & $\begin{array}{l}0.700^{* * *} \\
-0.615^{* *}\end{array}$ & $\begin{array}{l}0.841^{* * *} \\
-0.342\end{array}$ & $\begin{array}{l}-0.055 \\
-0.946^{* * *}\end{array}$ & $\begin{array}{c}-0.077 \\
-0.836^{* * *}\end{array}$ & $\begin{array}{l}-0.358 \\
0.913^{* * *}\end{array}$ & $\begin{array}{l}0.831^{* * *} \\
-0.274\end{array}$ \\
\hline $\begin{array}{l}\text { Density } \\
\text { All species } \\
\text { Body size }\end{array}$ & 0.127 & -0.476 & -0.061 & 0.262 & -0.306 & -0.231 & -0.127 & 0.175 & 0.040 & $0.568^{* *}$ \\
\hline $\begin{array}{l}\text { Small } \\
\text { Medium } \\
\text { Large }\end{array}$ & $\begin{array}{c}-0.214 \\
0.399 \\
-0.336\end{array}$ & $\begin{array}{l}-0.630^{* * *} \\
-0.362 \\
0.694^{* * *}\end{array}$ & $\begin{array}{c}0.060 \\
-0.196 \\
0.570 \text { ** }\end{array}$ & $\begin{array}{c}0.453^{*} \\
0.024^{*} \\
0.658^{* * *}\end{array}$ & $\begin{array}{c}0.032 \\
-0.567 * * \\
0.492 *\end{array}$ & $\begin{array}{c}0.033 \\
-0.467 * \\
0.721 * * *\end{array}$ & $\begin{array}{c}0.195 \\
-0.310 \\
-0.493^{* *}\end{array}$ & $\begin{array}{l}0.442^{*} \\
0.008 \\
-0.628^{* *}\end{array}$ & $\begin{array}{c}-0.336 \\
0.307 \\
0.139\end{array}$ & $\begin{array}{c}0.783^{* * *} \\
0.306 \\
0.283\end{array}$ \\
\hline $\begin{array}{l}\text { Habitat type } \\
\text { Forest species } \\
\text { Open land species }\end{array}$ & $\begin{array}{l}-0.327 \\
0.795^{* * *}\end{array}$ & $\begin{array}{l}-0.692 * * * \\
0.471\end{array}$ & $\begin{array}{c}0.031 \\
-0.155\end{array}$ & $\begin{array}{l}0.467 * \\
-0.413^{*}\end{array}$ & $\begin{array}{c}0.181 \\
-0.822^{* * *}\end{array}$ & $\begin{array}{l}0.123 \\
-0.597 * *\end{array}$ & $\begin{array}{c}0.353 \\
-0.841 \text { *** }\end{array}$ & $\begin{array}{l}0.570^{* *} \\
-0.742^{* * *}\end{array}$ & $\begin{array}{l}-0.490^{*} \\
0.947 * * *\end{array}$ & $\begin{array}{l}0.819^{* * *} \\
-0.550^{* *}\end{array}$ \\
\hline $\begin{array}{l}\text { Species diversity }\left(H^{\prime}\right) \\
\text { Species evenness }\left(J^{\prime}\right)\end{array}$ & $\begin{array}{l}0.146 \\
0.144\end{array}$ & $\begin{array}{l}0.902^{* * *} \\
0.901^{* * *}\end{array}$ & $\begin{array}{l}0.411 * \\
0.416^{*}\end{array}$ & $\begin{array}{l}0.219 \\
0.223\end{array}$ & $\begin{array}{l}-0.020 \\
-0.020\end{array}$ & $\begin{array}{l}0.256 \\
0.258\end{array}$ & $\begin{array}{l}-0.749^{* * *} \\
-0.751^{* * *}\end{array}$ & $\begin{array}{l}-0.874^{* * *} \\
-0.874^{* * *}\end{array}$ & $\begin{array}{l}0.580^{* *} \\
0.579 * *\end{array}$ & $\begin{array}{l}-0.222 \\
-0.216\end{array}$ \\
\hline
\end{tabular}




\section{Discussion}

Unexpectedly, species richness, density, body size, habitat type, species diversity, and species evenness did not differ between the different urban green areas. Furthermore, the community structure of ground beetles was similar in different areas. It seems that ground beetle communities formed by the effect of urbanization may become similar regardless of area. Ishitani et al. [23] showed that in urban habitats, large-sized forest specialists may completely disappear, whereas small-sized forest specialists and medium-sized habitat generalists were in higher abundance. Fragmentation and isolation as well as lower habitat quality of remnant urban habitat patches may cause generalist species to increase [13]. Lee and Ishii [24] studied riverbank, urban park, rice paddy, and coppice remnants in southern Osaka and showed that forest specialist, open-habitat specialist, large-sized, and endemic species have been reduced by urbanization. In our study, four large-sized forest species (Carabus yaconinus, Leptocarabus kumagaii, Haplochlaenius costiger, and Galerita orientalis) were recorded. Ishitani et al. [23] considered C. yaconinus and H. costiger as forest generalists. L. kumagaii and G. orientalis might be forest generalists based on collected records such as riverbanks, paddy fields, and urban green areas around forests in previous studies $[20,24,25]$. Among three dominant species, Synuchus nitidus and Dolichus halensis were considered forest generalist and habitat generalist, respectively [24]. This result seems to be consistent with previous studies.

Remnant forests may be one of the reasons why ground beetle assemblages were similar regardless of area. Although SU was the smallest area in this study, 22 ground beetle species were recorded, and this value was higher than the average (20 species). SU is located near Hatadaimyou temple where there are remnant forests dominated by evergreen oaks (Quercus species). Forests associated with shrines and temples are recognized as important components of urban green spaces and can potentially function as a key role in ecosystem conservation in urban areas [17]. Although urban forests have less species richness and abundance and different species composition and dominant species compared with rural forest, they can provide habitats for wildlife and potentially be used as stepping stones in the urban green space network $[17,26]$. Connectivity for ground beetles in urban areas will be another important factor. Both UM and TA are located in landfill areas. However, species richness in UM was the highest, whereas that in TA was the lowest. UM is located near the mouth of Yamato River, whereas TA is connected to inland with two bridges. Yamato River is a class A river in the Kansai region and flows from Nara and Osaka Prefectures to the Osaka Bay [25]. Lee and Ishii [25] reported that 53 ground beetles were found in various places such as gravelly riverbeds, sand lands, and grassy riverbanks in Yamato River. Among ground beetles found in UM, 86\% species composition was the same as that found by Lee and Ishii [25]. In addition, this result showed that Carabus yaconinus was collected in IZ, KU, and $\mathrm{KM}$, which are connected to natural habitats. Lee and Ishii [24] reported that Carabus yaconinus was not found in urban parks which are separated from natural forests in southern Osaka. Lee and Kwon [16] suggested that short-winged Carabidae species, poor dispersers, disappear in fragmented forests. These species may not be able to disperse through corridors or stepping stones. Our results suggest that remnant forests and connectivity will contribute to keeping ground beetle diversity in the urban area.

Although there is no significant relationship between ground beetle communities and area, community indices were positively or negatively correlated with area. Among them, ground beetle species richness, species diversity, and species evenness showed positive correlations with area. Urban area and road were negatively correlated with species richness of all species, small-sized species, medium-sized species, large-sized species, open land species, and density of large-sized species and open land species, and species diversity and species evenness. Koivula and Vermeulen [27] showed that carabid populations isolated by highways were significantly affected by patch size, and forest carabids rarely cross roads. Keller and Largidèr [28] reported that the isolation caused by major roads has a significant impact on the genetic structure of ground beetle populations. 
Urbanization substantially influences all levels (species group, population, and community) of the biological organization of ground beetles living in urban green areas [13]. Our results were consistent with previous studies. However, there are no uniform patterns in year, field, park and green space, forest, or open space with community index. Future studies should increase the sample size to enhance the statistical rigor.

\section{Conclusions}

Our results suggest that there is no significant relationship between ground beetle communities and area. However, community indices were positively or negatively correlated with area. The changes in paddy, field, park and green space, forest, and open space associated with the increasing urban area and road greatly influenced species composition and the similar community structure remained. Remnant forests and connectivity were important factors to conserve ground beetle diversity in urban areas. The urban green space network will be essential for biodiversity conservation in an urban ecosystem. As cities expand, decision-makers should invest in preserving and restoring remnant habitats and their connectivity to the urban green space network.

Author Contributions: Conceptualization, writing and editing-original draft preparation and supervision, J.-W.P. and C.M.L.; data analysis, J.-W.P.; validation and literature review, J.-W.P. All authors have read and agreed to the published version of the manuscript.

Funding: This research received no external funding.

Institutional Review Board Statement: Not applicable.

Informed Consent Statement: Not applicable.

Data Availability Statement: Not applicable.

Acknowledgments: We wish to express our sincere thanks to M. Ishii and N. Hirai (Osaka Prefecture University), and T. Hirowatari (Kyushu University) for their kind help and suggestions during the survey.

Conflicts of Interest: The authors declare no conflict of interest.

\section{References}

1. McDonald, R.I.; Kareiva, P.; Forman, R.T.T. The implications of current and future urbanization for global protected areas and biodiversity conservation. Biol. Conserv. 2008, 141, 1695-1703. [CrossRef]

2. McKinney, M.L. Effects of urbanization on species richness: A review of plants and animals. Urban Ecosyst. 2008, 11, 161-176. [CrossRef]

3. Elmqvist, T.; Fragkias, M.; Goodness, J.; Güeralp, B.; Marcotullio, P.J.; McDonald, R.I.; Parnell, S.; Schewenius, M.; Sendstad, M.; Seto, K.C.; et al. Urbanization, Biodiversity and Ecosystem Services: Challenges and Opportunities; Springer: Dordrecht, The Netherlands; Heidelberg, Germany; New York, NY, USA; London, UK, 2013.

4. United Nations. World Urbanization Prospects: The 2018 Revision; United Nations, Department of Economic and Social Affirs, Population Division: New York, NY, USA, 2018.

5. Magura, T.; Lövei, G.L.; Tóthmérész, B. Conversion from environmental filtering to randomness as assembly rule of ground beetle assemblages along an urbanization gradient. Sci. Rep. 2018, 8, 1-9. [CrossRef]

6. Martinson, H.M.; Raupp, M.J. A meta-analysis of the effects of urbanization on ground beetle communities. Ecosphere 2013, 4, 60. [CrossRef]

7. Piano, E.; Souffreau, C.; Merckx, T.; Baardsen, L.F.; Backeljau, T.; Bonte, D.; Brans, K.I.; Cours, M.; Dahirel, M.; Debortoli, N.; et al. Urbanization drives cross-taxon declines in abundance and diversity at multiple spatial scales. Glob. Chang. Biol. 2020, 26, 1196-1211. [CrossRef]

8. Elek, Z.; Lövei, G.L. Patterns in ground beetle (Coleoptera: Carabidae) assemblages along an urbanisation gradient in Denmark. Acta Oecologica 2007, 32, 104-111. [CrossRef]

9. Lee, C.M.; Park, J.W.; Kwon, T.-S.; Kim, S.-S.; Ryu, J.W.; Jung, S.J.; Lee, S.K. Diversity and density of butterfly communities in urban green areas: An analytical approach using GIS. Zool. Stud. 2015, 54, 4. [CrossRef]

10. Magura, T.; Horváth, R.; Tóthmérész, B. Effects of urbanization on ground-dwelling spiders in forest patches, in Hungary. Landsc. Ecol. 2010, 25, 621-626. [CrossRef]

11. Rainio, J.; Niemelä, J. Ground beetles (Coleoptera: Carabidae) as bioindicators. Biodivers Conserve. 2003, 12, 487-506. [CrossRef]

12. Stewart, A.J.A.; New, T.R.; Lewis, O.T. Insect Conservation Biology; CABI: Wallingford, UK, 2007. 
13. Magura, T.; Lövei, G.L. Consequences of urban living: Urbanization and ground beetles. Curr. Landsc. Ecol. Rep. 2020, 6, 9-21. [CrossRef]

14. Hartley, D.J.; Koivula, M.J.; Spence, J.R.; Pelletier, R.; Ball, G.E. Effects of urbanization on ground beetle assemblages (Coleoptera, Carabidae) of grassland habitats in western Canada. Ecography 2007, 30, 673-684. [CrossRef]

15. Magura, T.; Lövei, G.; Tóthmérész, B. Does urbanization decrease diversity in ground beetle (Carabidae) assemblages? Glob. Ecol. Biogeogr. 2010, 19, 16-26. [CrossRef]

16. Lee, C.M.; Kwon, T.-S. Community structure, species diversity of insects (ants, ground beetle), and forest health in the Hongneung Forest. J. Korean Soc. For. Sci. 2013, 102, 97-106. [CrossRef]

17. Buczkowski, G.; Richmond, D.S. The Effect of Urbanization on Ant Abundance and Diversity: A Temporal Examination of Factors Affecting Biodiversity. PLoS ONE 2012, 7, e41729. [CrossRef] [PubMed]

18. Ueno, S.-I.; Kurosawa, Y.; Sato, M. The Coleoptera of Japan in Color; Hoikusha Publishing Co., Ltd.: Osaka, Japan, 1989; Volume II.

19. Lee, C.M. Ecological Study on the Ground Beetle Assemblages of Urban Green Areas in Japan. Ph.D. Thesis, Osaka Prefecture University, Osaka, Japan, 2009.

20. Lake Biwa Museum. Ground Beetles of Satoyama, Shiga. 2021. Available online: https://www.biwahaku.jp/research/data/ gomimushi/kamei_list.html (accessed on 12 March 2021).

21. Lee, C.M.; Kwon, T.-S. Response of ground arthropods to effect of urbanization in southern Osaka, Japan. J. Asia-Pac. Biodivers. 2015, 8, 343-348. [CrossRef]

22. R Core Team. R: A Language and Environment for Statistical Computing; R Foundation for Statistical Computing: Vienna, Austria, 2021; Available online: https:/ / www.R-project.org/ (accessed on 1 April 2021).

23. Ishitani, M.; Kotze, D.J.; Niemelä, J. Changes in carabid beetle assemblages across an urban-rural gradient in Japan. Ecography 2003, 26, 481-489. [CrossRef]

24. Lee, C.M.; Ishii, M. Species diversity of ground beetle assemblages at urban greeneries in southern Osaka, central Japan. Jpn. J. Environ. Entomol. Zool. 2009, 20, 47-58.

25. Lee, C.M.; Ishii, M. Species diversity of ground beetle assemblages in the riverbed of the Yamato River. Jpn. J. Environ. Entomol. Zool. 2009, 21, 15-28.

26. Kong, F.; Yin, H.; Nakagoshi, N.; Zong, Y. Urban green space nextwork development for biodiversity conservation, Identification based on graph theory and gravity modeling. Landsc. Urban Plan. 2010, 95, 16-27. [CrossRef]

27. Koivula, M.; Vermeulen, H.J.W. Highways and forest fragmentation. Landsc. Ecol. 2005, 20, 911-926. [CrossRef]

28. Keller, I.; Largiadèr, C.R. Recent habitat fragmentation caused by major roads leads to reduction of gene flow and loss of genetic variability in ground beetles. Proc. R. Soc. Lond. 2003, 270, 417-423. [CrossRef] [PubMed] 